\title{
On the Training Mode of School-Enterprise Cooperation in Personnel
}

\author{
Jun Wei Shi
}

\author{
Agricultural University of Hebei,Baoding, Hebei, People’s Republic of China,stonejw@163.com
}

\author{
Keywords: School-Enterprise cooperation; Personnel training; Engineering alternating,Dual System
}

\begin{abstract}
On the current situation and development of domestic and foreign colleges, enterprises running mode, the paper launched an in-depth analysis and research, and put forward suitable for our country, for our employers to train for different needs, with the overall quality of talent and ability to innovate suggestions and recommendations Education. Connotation and characteristics of specific research colleges, enterprises and educational models, meaning a clear implementation, explore ways to implement and analyze the problems, coping strategies and recommendations made to improve the reference for the future shape of our colleges, enterprises running mode.
\end{abstract}

\section{Introduction}

The traditional school system, in order to impart knowledge based, played down the students' practical ability, can easily cause a serious gap, qualifications and abilities of teaching and learning, learning and use of severe dislocation, training objectives out of touch with the market demand. Many shortcomings of the traditional school system, the school-enterprise cooperative education model came into being, it is a kind of students' overall quality, comprehensive ability to focus on competitiveness and employment, and business use of two different educational school environment and educational resources take students to participate in classroom teaching and practice of organic combination, the employer needs for different cultures, with the overall quality of talent and ability to innovate education mode. The advantage is that students develop a sense of having a strong industry and applied technology capabilities to quickly qualified job after job work. Education and low cost, very flexible, advanced, adaptability. Business students practice skills to operate a shooting training to enable students to master the ability to work real jobs, students solve problems in school career focused, technology applied pre-job training and employment for all. In contact with the business process, corporate culture on students penetration, help enhance student awareness projects, improve enthusiasm and initiative, practical work, style simple, harmonious relationships. Graduation can quickly enter job roles, achieving Zero posts.

Running from foreign colleges, enterprises and cooperative education (Co-operative Education), co-education in a foreign country for nearly a hundred years of history, has been formed three main modes: First, the US and Canada, CBE (Competency based education) mode ; Second, the United Kingdom and Australia models; three is Germany represented "dual system" mode. These three models, although the manifestations and different characteristics of specific operations, but they also have something in common: both in the direction of student employment, student post teaching job, and has a strict management system and ultimately to promote and promoting educational reform.

Colleges, enterprises and educational practice, so that "admissions that recruitment, employment upon graduation," become a reality, not only to protect the school's students and student employment, but also to protect the overall quality of teaching. Educational colleges, enterprises solve production practice teaching schools needed space, inadequate equipment, tools, instructors and other issues. Student internships directly into the plant, it enables Specialized knowledge they have learned with practice closely together. This improves the maximum extent possible courses teaching quality, to make up for the shortage of textbook knowledge behind social development, teaching content and social needs of the school's synchronized, thus ensuring the continuous improvement of teaching. According to business needs and the needs of students teaching reform, enable students to learn more about the practicality of knowledge and practical skills to master better, make the school all school 
behavior and business practice, schools and businesses can derive great in return, in order to achieve the perfect blend of schools and businesses.

\section{Our colleges, enterprises and educational problems of}

Although colleges, enterprises and schools in the country is in full swing, but the various models are not perfect, there are many problems, embodied as follows:

Existing legal provisions for the colleges, enterprises and schools in the blank. In the current laws and regulations, the lack of specific colleges, enterprises and schools, the operability of the laws, regulations guiding mention only some of the provisions in the "Education" and "Vocational Education Law", by bringing huge space difference and arbitrariness of law enforcement issues, leading to disputes continue in practice. For the legal status of government regulations is unknown, there is no legal responsibilities and obligations specified in the government, making the role of government in running the school and enterprise hard to function properly. Relevant laws and regulations to implement safeguards ineffective sanctions and the lack of specialized oversight body, the event of a dispute difficult to resolve disputes.

Existing education management system is not conducive to the colleges, enterprises and educational development. Legal stability and lag decided to modify a law is a huge and lengthy project, as to complement and improve national policies and laws are reflected its superiority. However, in the colleges, enterprises and schools in our country for so many years since the implementation of the relevant national policies but very few. Colleges, enterprises and schools, and cooperation with enterprises can enable students to quickly adapt to market demand, which requires companies to participate in the school building. However, China's college education is completely managed by the executive branch, the lack of effective education industry guidance. Schools in cooperation with non-governmental enterprises active in the actual operation of the responsibilities, rights and benefits of the more obscure provisions, the parties can not establish long-term, stable and mutually beneficial cooperation mechanism, which restricts the colleges, enterprises and educational in-depth, ongoing and healthy development.

The school's own educational colleges, enterprises lack the strength to carry out restricted. School-enterprise cooperation must be on the basis of mutual benefit to healthy development. Due to historical reasons, most of the experimental conditions are not perfect institutions, research capacity and level of teachers is not high, so that the way of poor cooperation between schools and businesses, affecting the conduct of school-enterprise cooperation. This is also another reason for cooperation between enterprises and schools are not enthusiastic high. Schools open joint school of thought is not enough. Main features: First, the colleges, enterprises and schools to carry out only as a way for students to solve the original production practice mode, undue emphasis on professional counterparts, the students did not really overall quality and comprehensive ability to improve students' employability and competitiveness as The primary task to be considered. Second, many schools are still applied in the past for production internship ways impossible to escape the circle of state-owned enterprises in the search for joint education jobs, thus making joint educational road gets narrower. Third, in order to facilitate the management of many schools, students often want to schedule in a few work units, due to one-off units can accept fewer than a dozen people, thus causing great difficulties to carry out colleges, enterprises and schools.

Lack of economic development for colleges, enterprises and schools of internal driving forces. School education colleges, enterprises under certain historical conditions and developed, because our country is in a transition period, the market economy system is not perfect, inter-regional, inter-sectoral, inter-enterprise economic development is very uneven, and many jobs are still being occupied by traditional labor. Positive cooperation between enterprises and schools is not high. On the other hand, China's job market is still not standardized, high consumption of talent, vocational graduates difficult. Development of higher vocational education is more government action, has not 
yet become the urgent desire of enterprises.

There is a big school of passivity in the teaching arrangements and employment. Colleges, enterprises and educational requirements for school students must be trained to meet the needs of enterprises. To enable students to train themselves out to meet this need, in order to facilitate the development of better schools, schools are often passive in the teaching arrangements in accordance with the requirements of the enterprise can only adjust the curriculum, and different business or a different specialty in curriculum there are different requirements on, which adds to the school's passivity. If the school is fully courses according to the needs of enterprises, such costs will greatly enhance the teaching, nor the normal teaching order. This requires that the school in ensuring the maintenance of normal teaching order situation, can not adhere to the traditional teaching model, should be practical, both to ensure that students learn enough things in school, but also to meet the business requirements to ensure that these things.

In addition, students in the school there are a lot of employment passive. Because colleges, enterprises and schools, corresponds to an enterprise, the students into the plant when it is normally provided by the enterprise have the final say, if the company requires students to advance into the plant is likely to provoke students complain, too pay the tuition at the school did not learn too many things; but too late into the plant might have attracted students and parents speculation, bring bad influence to the reputation of the school.

\section{Running Mode colleges, enterprises and initiatives Suggestions}

According to the characteristics and problems of current educational colleges, enterprises, and put forward some suggestions and measures.

Training objectives have applied. By colleges, enterprises and schools, to train in the production, operation, management and service lines, can design, planning, business decisions into real products or services of a high-level technical skills, talents or intelligence operations personnel.

Have occupational specialty. Professional setting should have a strong market concept, the relationship between supply and demand in the job market should be starting, all the market needed to run a professional, who has saturated the market closed on a professional, attention must be focused professional career and job specific.

Teaching contents and curriculum system targeted. Should be from the actual needs of a professional job of starting the job that needed knowledge, skills, ability to integrate the current production and management experience in the most widely used the latest technological achievements included lesson plans, build modular teaching content and curriculum, and the latest technological achievements taught to students, so that students master.

Teachers have "dual role". The key to improve the quality of personnel training of teachers, teacher colleges, enterprises should have a strong "Double" quality, both lecturers and professors, but also engineers, accountants, technology division.

In the school system, in view of the existing school system as well as a variety of regional development in different parts of our country, to encourage the country's schools and businesses to choose their actual school system, such as an alternating pattern engineering, business and school cooperation "dual system "Vocational Education mode or both of the above types of pattern features mixed mode. For professional setting and curriculum to reflect local social, economic and cultural characteristics; To take full advantage of community resources to schools, colleges and universities are taking full advantage of the resources to serve the construction of the political, economic, cultural, carry a variety of academic, each forms, such as a variety of educational models and flexible way to measure social development provides a full range of services.

On the management, for a variety of our existing school system, management should also be appropriate diversification. Eligibility criteria for the use of technical education and industry oversight of state intervention in parallel. The establishment of a sound supervisory body to oversee 
the administrative staff to perform their duties behavior, any member of the supervisory bodies in addition to representatives from the investors, but also by a keen vocational education, colleges, enterprises concerned about the development of school education inside and outside experts. Supervisors have the right to attend the shareholders' meeting and administrative meetings of the two organizations to monitor, the right to speak at the meeting of shareholders and principals and other administrative personnel in violation of the law and the purpose of vocational education and behavior in violation of the Constitution the right to request that they be corrected.

To strengthen the role of colleges, enterprises and social forces to promote the school's. In terms of investment channels, multi-channel financing, role of the government, enterprises, organizations, private colleges, enterprises and educational enthusiasm face four investment. On school functions, enhanced radiation effects on society as a whole. Colleges, enterprises and educational institutions to make the formal and non-formal education coexist by a single formal education, academic education coexist single to academic and non-academic education, a single pre-vocational education for pre-service and post-education coexist, a single education direction of education to instruction combined with employment growth, so that vocational education institutions as a human resource development center.

In summary, schools and businesses through a variety of ways of cooperation in running schools, students and employees to provide a combination of theoretical and practical platform to achieve maximum resource sharing and collaborative learning, is to meet business needs and promote social employment effective measures are boosters of economic development, but also the only way for the construction of a harmonious society.

\section{Conclusion}

In short, through colleges, enterprises, production and education combined, to change the traditional single mode of education, you can take advantage of a good use of resources and corporate institutions, universities and enterprises to realize win-win. From the school in terms of corporate personnel training needs for the school proposed to promote the theory and practice of teaching reform schools; colleges, enterprises, help to improve the overall quality of students; help improve the faculty building. From the business perspective, colleges, enterprises carry out, in favor of corporate human resources and development of new products, to bring greater efficiency; the use of the school to provide enterprises with talent, technology, information and other advantages to develop production, create some economic; schools participating personnel training, enterprise development plans and strategies, enhance their development potential.

\section{References}

[1] J.G.Wang, Y.F. Guo, Work-integrated Learning on Work- integrated Learning Modefor Higher Vocational College Personal Training,J. Guangzhou Chemical Industry. Vol.10 (2014) 243-244.

[2] L.Y. Gao, Exploration on Talent Training Approaches in School-Enterprise Cooperation of Open Education,J, Educational Development.17 (2014) 80-84.

[3] Y.Q. Bai, S.X.Dai, A Probe into the All-win Mode Based on In-depth School-enterprise Integration and Its Practice ,J. Journal of Chongqing Electric Power College. 6 (2014) 13-15.

[4] X.L..Zeng, K.F Ning, Investigate School-enterprise Cooperation Personnel Training Mode in Colleges and Universities,J. China Educational Technology and Equipment.5 (2014) 126-127.

[5] Y.L.G, The Sehool-enterprise cooperation is the way for our Modern enterprises go out Talent dilemma,D. ShanxiUniversity,2011.

[6] Y.Q.Yang, On the Role of School-Enterprise Cooperation in Personnel Training,J. Value 
Engineering.2 (2012) 204-205.

[7] L.H.Sun.A New Mode of Exploration School Enterprise Cooperation,J. Journal of Qinghai Normal University (Philosophy and Social Sciences) .11 (2013) 23-26.

[8] L.Xin, The Analysis of Factors on Constructing Long-term Mechanism of School-Enterprise Cooperation,J.Journal of Baotou Vocational \& Technical College.9(2012) 54-56.

[9] G.C. Xing, On establishing long-term mechanism of school-enterprise cooperation,J. Journal of Beijing Vocational College of Finance and Commerce. 6(2012) 21-24.

[10] F.Q.Sun, X.Y. Zhang, Study on the " School Enterprise Community" Talent Training Mode,J. Shipbuilding Vocational Education. 4(2013) 13-15. 